\title{
The Semiotics of the Medical Face Mask: East and West
}

\author{
Massimo Leone \\ University of Turin, Turin, Italy; Shanghai University, Shanghai, China \\ massimo.leone@unito.it
}

\begin{abstract}
After a concise survey of the state of the art on the semiotics of the mask and on studies in humanities and social sciences about medical face masks, the essay provides anecdotic evidence about differences in the semiotics of medical face masks in Europe and in the 'Far East', especially Japan, China, and Korea; it proposes a semiotic grid for decoding the phenomenology and meaning of the medical face mask; it concludes with some general observations on the change of the meaning of the face during the current pandemic.
\end{abstract}

\section{Keywords}

medical face masks - semiotics - 2020 covid-19 pandemic - face

We all die with a mask on our features. GIUSEPPE TOMASI DI LAMPEDUSA, The Leopard, $195^{8}$ 
The mask is a device of hybridity. ${ }^{2}$ The present article, which aims at semiotically dealing with protective, medical face masks, is a hybrid too. It originated both in contingency - the increasingly widespread usage of such masks throughout the world as a response to the planetary diffusion of the covid19 virus in 2020 - and in the author's long-term interest in the semiotics of veiling devices. ${ }^{3}$ The article hybridizes contents too: on the one hand, a scholarly survey on the semiotic literature on masks, and a semiotic analysis of the meaning of medical face masks in the current pandemic; on the other hand, a series of personal anecdotes contributing everyday life evidence to academic discussion. The intent of the admixture is hybrid too, seeking to strike a balance between attention to current events and scholarly detachment, empathy for the painful conditions of fellow humans and anthropological and historical perspective. The pages that follow, as a consequence, seek to both deciphering the epochal changes that the 2020 pandemic is begetting in human cultures and reframe such transformations in a long-term cultural history and semiotics of the mask. The hope is that such double view, one of proximity and distance at the same time, might be helpful in the process of finding new interpretations and new solutions to the many conundrums that the pandemic is imposing on the life of present-day human communities.

After a concise survey of the state of the art on the semiotics of the mask and on studies in humanities and social sciences about medical face masks, the essay provides anecdotic evidence about differences in the semiotics of medical face masks in Europe and in the 'Far East', especially Japan, China, and Korea; it proposes a semiotic grid for decoding the phenomenology and meaning of the medical face mask; it concludes with some general observations on the change of the meaning of the face during the current pandemic.

1 This article results from a project that has received funding from the European Research Council (ERC) under the European Union's Horizon 2020 research and innovation program (grant agreement No 819649 - FACETS); a previous version of a short section of the article has been published in Social Semiotics.

2 A characteristic underlined by many students of the mask, starting from Mircea Eliade (Eliade 1964). See Walens (1983: 77): "Masks are the mechanism through which the past and the future, the alpha and the omega, of human existence are made analogous and obviated".

3 See Leone 2007, 2009, 2010, 2011, 2014a, 2014b, 2016, 2017, 2018a, 2018b, and Leone, Riedmatten, and Stoichita 2016; the parallel between masks and veils is not new in humanities and social sciences (Inglis 2018), but gains new momentum with the global adoption of medical face masks (Ricca 2020). 
Masks are an inevitable object for semiotic curiosity. The founding father of structuralist social sciences, the anthropologist Claude Lévi-Strauss, studied the masks of the populations of current British Columbia from a contrastive, structural point of view, comparing the plastic structure of the masks "swaihwé" (Salish) and "xwéxwé" (Kwakiutl) to that of the masks "dzonokwa" (Kwakiutl) in order to deal with the broader issue of style in human creativity (Lévi-Strauss 1975). In the same year, Boris L. Ogibenin (1975) - a member of the school of Moscow-Tartu, then head of the Sanskrit Department at the University of Strasbourg - sought to approach masks from a functional perspective, in order to interpret them as more than a mere device for magicoritual, theatrical and, then, artistic signification - a point of view predominant in the aesthetic literature on the topic - and, instead, understand them holistically, without separating the ritual domain from the surrounding culture and developing, thus, a typological inventory of masks. The dense article undertakes to answer, in particular, three questions:

Is itpossible to maketypological generalizations of a socio-anthropological nature from which one could predict if there exist (or existed) societies without a subculture of masks (and if such societies are known, then how is the absence of this specific variety of ritual, subsequently theatrical, and artistic culture compensated)? In which types of society (if their existence can be established) did masks penetrate as an absolutely essential part of the art of representation and portrayal? Finally, is it possible to find a relationship between the types of cultures and the types of masks used in them?

Ibidem: 1

In the same year, 1975, Umberto Eco published his semiotic opus magnum, the Trattato di semiotica generale ("treatise of general semiotics") (1975), then published also in English in 1976 (A Theory of Semiotics). In it, Eco does not specifically deal with masks, but use death masks as an example in the section of the book dealing with a "theory of sign production" and, in particular, with the concept of "similitude" in "iconism and similarity". According to Eco, indeed, dead masks are an instance of signs produced through congruence, "where two figures of equal size can be made to coincide or to fit on top of one 
another" (ibidem: 196). Yet Eco also adds that masks "make abstraction from matter, color, and differences in texture" (ibidem). ${ }^{4}$

Always in 1975, Alfred Gell published the monograph Metamorphosis of the Cassowaries: Umeda Society, Language and Ritual. Inspired by Lévi-Strauss's structural anthropology, the book aims at decoding ritual in Umeda society (Papua New Guinea), and devotes substantial attention to the meaning of masks. The innovative aspect of Gell's approach consists in his focusing on the dialectics between the face and the mask, and in considering the latter as a device that transforms the meaning of identity conveyed by the face itself. In a frequently quoted passage, Gell affirms:

In a sense, all the masks do is take up and elaborate certain expressive 'means' which are implicit in everyday usage - the same is true, for instance, of the expressive use of treatments of the penis in ritual ... where, once again, the usages of everyday life are taken up and modified in various ways in order to make symbolic statements.

GELL 1975: 3O1-2

Gell, moreover, stressed that the meaning of masks can be understood only if one considers not only what elements of nature they represent, but also what elements of the face they modify:

Mask styles take their point of departure, not from the fish, cassowaries, termites, or whatever entity they are overtly intended to represent, but rather from the human head itself: the mask is not an image of nature, but an elaboration of man.

Ibidem: 301

4 More recent semiotic contributions on masks include Marsciani 1990 (on the semiotics of the 'neutral mask'); Bettini 1991 (a collection of essays on the theme of duplicity, with semiotic contributions on the mask); Chateau 2006 (a semiotic analysis of the mask replacing the face in Picasso's Portrait of Gértrude Stein); Greco 2009 (a semiotic reading of Art Spiegelman's Maus, also focusing on masks worn by characters); Volli 2013 (on the relation between subjectivity, mask, and personhood); Beyaert-Geslin 2017 (on the visual forms of self-representation); Zang Ndong 2017 (a doctoral thesis on the semiotics of masks in Africa); Buch 2019 (a revised doctoral thesis on the influence of No theatre in French culture, with a seventh chapter devoted to the "Signification sémiotique du masque, du costume et du maquillage", pp. 179-222); Sanou 2019 (also on the semiotics of African masks). 
Goffman's seminal study of the face as self (The Presentation of Self), published in 1959, had already spread the scholarly conviction that the face itself is indeed a sort of mask, and that social interaction should be studied from a dramaturgical perspective:

It is probably no mere historical accident that the word person, in its first meaning, is a mask. It is rather a recognition of the fact that everyone is always and everywhere, more or less consciously, playing a role [...] It is in these roles that we know each other; it is in these roles that we know ourselves.

Ibidem: 19

Similarly, even before the boom of semiotics in the late 196os and 1970s, Roland Barthes, one of the initiators of the discipline, had already stressed, in his 1957 Mythologies, that the mythical face of Greta Garbo could be understood only as a mask embodying the dialectic tension between an ideal, Platonic face, and the substance of a visage:

And yet, in this deified face, something sharper than a mask is looming: a kind of voluntary and therefore human relation between the curve of the nostrils and the arch of the eyebrows; a rare, individual function relating two regions of the face. A mask is but a sum of lines; a face, on the contrary, is above all their thematic harmony.

BARTHES 1972 (1957): 57

1975, this annus mirabilis for the study of masks, is also the year of publication of an article by Ronald L. Grimes, entitled "Masking: Toward a Phenomenology of Exteriorization". Adopting as a methodological model the newly established discipline of kinesics (in 1970, Birdwhistell had published the seminal book Kinesics and Context), Grimes attempted a phenomenological description of masking, transversal to the different types and usages of masks. Grimes's fundamental question was "In what ways might we interpret the act of donning a mask regardless of who wears it and what it looks like?" (Grimes 1975:508). He elaborated four essential phenomenological types: 1) concretion; 2) concealment; 3) embodiment; and 4) expression.

In 1975, moreover, John J. Honigmann, Professor of Anthropology at the University of North Carolina at Chapel Hill, observed the Christmas season and associated ceremonies in the rural community of Altirdning. The resulting article, "The Masked Face" (1977), was pioneer in underlining a crucial 
phenomenon associated with mask: the propensity of masked people to "act out", even beyond the convenience of social order:

Masks influence behavior by doing something more than establishing anonymity. Their potency lies in the way they restrict the range of human expression emanating from the actor.

Ibidem: 275

Finally, 1975 was also the year of publication of a peculiar article by Michael Mair, an oculist who had also graduated in social anthropology. Mary Douglas organized a seminar for him at University College London, which then give rise to a heavily interdisciplinary article entitled "What Do Faces Mean?" (Mair 1975). In it, the author concluded that "The suggestion that faces are bons à penser - good to make meaning out of - is one that may appeal to social anthropologists. The task which we have currently set ourselves is to test our conjectures experimentally".

Strauss, Ogibenin, Eco, Gell, Grimes, and Mair, all writing in 1975, manifest a change of point of view in relation to the disciplines that had previously dealt with masks, that is, history of religion, comparative religions, history of theater, folklore, and anthropology. In inquiring about what the mask means, these approaches would often neglect a question that became central, instead, in structural anthropology and semiotics: how does the mask mean? Such a switch of angle led also to another major renewal of studies in the field. Concentrating on the language of the mask, and not merely on its symbolism, anthropologists adopting a semiotic approach could enlarge their focus, and consider both the mask per se and a whole series of "masking devices" with a similar function (such as the veil, for instance).

This slant was already found in Crocker (1977), which emphasized the relevance of masks for the study of the new field of "anthropology of identity":

The ethnographic and comparative study of identity is a promising one for social anthropology. The material and symbolic modes in which the self is defined, and how these are manifest in transactions with like and different others, may enable kinship studies to break free from its genealogical rut.

CROCKER 1977: 129

That was, then, further underlined in Tonkin (1979), which signalled it by writing "Mask" with a capital initial and, switching from studying the mask 
from the point of view of the observer to doing it from that of the face itself, defined the face as "the personality's most immediate mise en scène" (1979: 241).

In the 1980s, several studies were devoted to masks especially in ritual and artistic contexts, with keen attention on the dimension of signification. Crumrine (1983) voiced the consolidation of the new structural and semiotic approach by defining the mask as "the ritual transformation of the human actor into a being of another order" (Crumrine and Halpin 1983: 1). The same year, Greg Urban and Janet Wall Hendricks published in Semiotica an article entitled "Signal Functions of Masking in Amerindian Brazil", where they proposed a categorization of the main semiotic functions of masks: representational, emotive, indexical, and disguising. The already cited collection of essays Crumrine and Halpin (1983) inquired on the symbolism of masks in the Americas; Napier (1987) concentrated on how masks signify the paradoxes of transitional states, focusing on ancient Greek cases (the Satyr, the Gorgon) and comparing them with the iconography of Hindu masks in Bali; Markman and Markman (1989) dwelled on masks as "metaphors" in Mesoamerican rituals. ${ }^{5}$

Further research on the functions of the mask was carried on, in the 199os, by Pernet (1992), who adopted a mostly negative definitional approach, concentrating on what masks are not; ${ }^{6}$ and Pollock (1998), who surveyed most of the previous literature on the semiotics of masks, stressing the novelty of an approach based on C. S. Peirce's semiotics so to understand how they work and modify the identity of the face, itself to be construed as the result of ongoing semiosis. According to Pollock, what is essential is to take into account the paradoxical both iconic and indexical nature of the mask: ${ }^{7}$

5 Literature on masks in the 1980s also includes Jedrei 1980 (on North America, Africa, and Melanesia); Oettinger and Kenagy 1988 (on Mexico); Synnott 1989 and especially its II part, published in 199o, extending the concept of "mask" to makeup but also introducing the idea of the face as "battlefield".

6 Further research on masks in the 1990s include Dagan 1992, on the African mask tradition; another essay by Pernet (1992b), consisting in a reassessment of the relation between masks and women in ritual; the comparative collection Mack 1994; Tseëlon 1995, with a gender perspective, whose II chapter, on duplicity, explores how masquerade and embodied identity are intertwined in women's sartorial self-presentation; the exhibition catalogue and collection of essays Nunley 1999.

7 Literature on masks in the 2000 s includes Tseëlon 2001 and 2014 (on the gendered dimension of masks); Gary 2005 (an illustrated compendium on masks); after September 11, 2001, numerous works have been devoted to the Islamic veil and some of them compare veils and masks. See, for instance, Heath 2008. Among the most recent scholarly contributions on the topic: André, Dreyfus-Asséo, and Taylor 2010 (a collection of essays between psychoanalysis and ethnology); Belting 2013 (an ambitious cultural history of the face, with many references to masks); the exhibition books Ferino Pagden et al. 2009, Hershman et al. 2014, Chazot et al. 2015, and Musée du Quai Branly 2015; Twycross and Carpenter 2016 (on masks in Early Tudor 
masks are also and simultaneously icons and indexes of identity, and it is this conjunction of semiotic functions and fields that give the mask its particular form in any society and its particular fascination for anthropology. Ibidem: 594

The medical face mask differs from most masks studied by the anthropological, sociological, psychological, and semiotic literature on the topic. It is a mask that is not used in ritual but in everyday life. It is not primarily intended to modify the identity of the face but to protect the respiratory system. It is not worn out of custom but out of necessity. Its main type does not show any relevant decorations.

Yet, as the medical face mask becomes the most diffused facial device throughout the entire planet, even more than glasses, it ceases to be a mere functional object and acquires a more and more complex anthropological and semiotic status. It is not worn in rituals, yet wearing it increasingly tends to acquire a ritualistic aura; it is not essentially meant to change the face's identity yet it deeply does so, with a whole series of practices, tactics, and 'semiotic bricolage' actions aiming at controlling such loss of identity (personalization in wearing it, customization, decoration, adaptation to specific needs - those of the community of deaf people, for instance - irony, modification of facial and body behaviour so as to regain the identity lost because of the medical face mask, etc.); the necessity of wearing it is reinterpreted too, and turned into habit or even fashion; moreover, the progressive 'semiotisation' of the medical face mask leads to the creation of local cultures, in which this facial medical device interacts with pre-existing cultures of the face and of the mask. Developing a full-fledge semiotic and anthropological study of this new omnipresent object of the present-day social scenario is, therefore, turning more and more urgent.

My first anthropological encounter with surgical masks took place in 2016, when I was invited for a semester as Visiting Professor at the University of Kyoto, Japan. Taking the metro in Kyoto, Tokyo, and other Japanese metropolises was a semiotic adventure from many points of view, but one aspect of it was particularly striking: so many people in the wagons, including young

England); Filitz 2018 and Berlejung and Filitz 2018 (on masks in antiquity). For a recent survey, Inglis 2018. 
individuals, were wearing protective masks. I was also impressed by how many people would sleep in public transport, and gave a semiotic account of it in my 2019 book On Insignificance, claiming that sleeping in public in Japan was puzzling to western visitors because these had naturalized a semiotic ideology of public space as being dangerous, as being a place where one should remain alert. In a curious chiasm, the frequency of medical masks in public transport would signal an opposite semiotic ideology: whereas the air would not be a potentially dangerous element for most westerners, even in a crowded place such as a metro wagon, it definitely was such for the Japanese, who would systematically avoid breathing that same air in public transport. The difference was difficult to explain in exact terms: was it perhaps related to the experience of the SARS 2002-2004 epidemic, or of the 1995 Sarin Terror Attack in the Tokyo metro, or would it date from even earlier, and have as a tragic background Hiroshima and Nagasaki, and the disaster of the Japanese air contaminated with radiations?

In any case, my cultural shock with masks in Japan was not always dramatic. Once I was supposed to meet a Japanese colleague of mine at a bus stop near the Kyoto University of Arts and Design, where I was expected to give a lecture. Once at the bus stop, I waited and waited and waited, until I realized that the young lady sitting on the bench, engrossed in a book, was actually my colleague. I could not recognize her under an elegant face and head shield composed of a mask, sunglasses, scarf, and a hat. "I got a cold", she told me. And I suddenly remembered the first dinner to which I had been invited in Kyoto, at one of my colleagues' house, to eat "shabu-shabu" (I was still a carnivore then); I remembered that then I myself had a cold, and that I would sneeze and cough and blow my nose in tissues while at the table, in a series of acts and gestures that, to my gentle hosts, must have looked disgusting and uncivilized. Later I learned that, in Japan, people would commonly wear masks during cold months and flu periods, and not only in order to protect themselves from the possibly contaminated air, but also in order to protect the air and others from one's contaminated breath. That would be a sign, to me, of a different idea of the individual in relation to society, and also of a different notion of the dialectics between immunity and community: protecting oneself and protecting the group were indeed seen as one.

Yet, no matter I could now rationalize and even praise the custom of wearing masks against potential risks of contagion, deeply rooted aesthetic habits of mine could not vanish all of a sudden; I would still find it strange, or even uncomfortable, to have a conversation with Japanese colleagues or students of mine wearing masks, concealing their noses, mouths, lips, smiles, and labials. I had the impression not to know at which part of the face I was supposed 
to look. Then I also learned that, in Japan, it was actually more polite not to insistently stare at the face of the interlocutor at all, and to avoid such direct gaze at the other's face especially if the interlocutor was someone whom tradition would entitle with particular deference; for instance, an elderly woman. I began to consider the hypothesis that one of the reasons for the cultural acceptance of protective masks in Japan was actually the fact that the face would not be used in the same way in Japanese conversations as it was in the western ones. Protective masks would not bother people in Japan because it was not as important there as in Europe to look at someone's eyes or even face while having a conversation with such person, and it was even frowned upon as a manifestation of impoliteness, or at least as a sign of being a foreigner not sufficiently acquainted with Japanese customs. Only later on, in the frame of my European research project on the face, I would draw more definite conclusions from those initial insights, and elaborate on the western obsession for matching personality, voice, and face.

When leaving Kyoto for good in late April 2016, I was at the airport with a small amount of coins in my pockets. I decided to buy some silly souvenirs and, together with colourful umbrellas, small music speakers, and other paraphernalia, I also purchased some Japanese protective masks, which I never used and which, ironically, as I am writing the present paper, are still in some remote corner of my Turin house, while I am stranded by the 2020 pandemic, struggling to find protective masks, on the western coast of France. At that time, those masks were an exotic souvenir to me, and as such they were sold to western tourists in the airport of Kyoto. I could never imagine, then, that they would become some of the most coveted items of the planet during the outburst of the 2020 pandemic.

A few weeks before leaving Japan, I also received another insight about protective masks and, in this case too, it would then take me more than ten years to fully come to terms with it. At another dinner, following the presentation of the Japanese translation of Roberto Calasso's The Marriage of Cadmus and Harmony, in the beautiful Kennin-ji zen temple, the Italian intellectual expressed his contempt for the Japanese habit of wearing masks in public transport. He called the faces covered by masks "becchi", "beaks", in Italian. Ten years later, these contemptuous words would still resonate in my mind as I, although still judging them as quite chauvinistic, came nevertheless to realize that they were pointing at a major semiotic problem concerning protective masks in the west: people would visually receive them as snouts, as muzzles, and, therefore, as contradicting the essential face/muzzle divide through which many if not all Indo-European cultures articulate and single out the visual and verbal semantics of the human face. I would also realize, much later, 
than the ancient Greek and Latin word for "muzzle" would actually also refer to beaks. By virtue of a different "ontological ideology" was perhaps Japan not equally obsessed with the separation of muzzles and faces, beaks and visages?

I still do not know. Yet I understood, already during my Japanese sojourn, that protective masks can and do undergo a semantic and aesthetic reframing, which concerns both their form and their function. As regards the first element, form, a few rides in the metro of Tokyo were indeed sufficient for one to realize that protective masks were not usually the same in Ebisu or Asakusa, among the wealthiest areas of the city, on the one hand, as in Kamagasaki or Sanya, among the poorest ones, on the other. Alongside the regular and anonymous medical masks, in the richest areas of the metropolis some passengers would display particularly lavish protections, with elaborate forms, colours, brands, and even materials. Masks made with the eggshell of ostrich, I was told, were the ultimate luxury, for they would be fabricated using a material with both an aura of exclusivity and the best porosity in breathing in and out. Protective masks were also re-functionalized through individual practices of meaning that, while keeping their original purpose of protecting the respiratory system of individuals wearing them, were also superimposing, on top of this protective function, other secondary means. During informal discussion in class, for instance, several, especially female students of mine would reveal that they would wear masks not only in crowded places like the metro or other means of public transport, and not exclusively during cold or flu periods, but also in the public environment per se, and without temporal or seasonal restrictions. When asked what the reason for that attitude might be, they would reply that, with masks on, they would feel more at ease, more protected from alien gazes. Masks in Japan had, therefore, been re-functionalized in the sense of allowing immunity not only from unwanted viruses and potentially contaminated air but also from undesired staring and, more broadly, from unwished visibility in the open.

That prompted the consideration that, in order to fully understand the cultural semiotics of protective, medical masks in Japan one should refer them, on the one hand, to the very rich local history and culture of masks, an essential ingredient of Japanese theatre in both the forms of Kabuki and especially No, exactly like in other theatrical world traditions including the western one; on the other hand, one should also comprehend such semiotics, with its complex range of re-semantisations and re-functionalisations, in relation to the equally complex phenomenological and semiotic category of the veil. Protective masks in Japan were used as traditional masks when they were worn so as to signify a particular identity (for instance, that of the well-behaved citizen who does 
not want to contaminate others), but they were also worn as veils when their primary purpose, inextricably interwoven with the first one, was to hide the face, or at least a part of it, from external gazes.

In other words, the protective mask in Japan had to be understood under the broader category of the mask, but also under the more encompassing category of the veil. The necessity of such comprehension was itself revealed to me one day when, during a trip to Kanazawa, on an unexpectedly cold day of early spring, I entered a mall to buy a raincoat so as to protect myself from the sudden stiff winds. In the fitting room, to my surprise, I found a box of thin paper veils in the shape of an open bag that individuals were evidently supposed to wear around their heads while trying cloths on. I did so, and took a picture of myself in the mirror, all dressed up with a suit and tie and this thin veil on my head, my face blurred underneath it, my look disquieting like that of a killer in a Japanese horror movie. I was instructed, then, that the purpose of those thin tissue paper shells was to avoid staining new cloths with traces of makeup while trying them on.

It came to me that that particular veil, which was also a mask-although one that would not be displayed to anyone except to oneself in the mirror of a dressing room - was to be interpreted as item and as combination of form and function both stemming from a broader not only visual but also tactile civilization, from a culture in which anthropologists have already underlined the importance of the principle of wrapping: the proverbial wrapping of Japanese presents, so elaborate as to be even more socially important than the gifts it contains, but also the wrapping of other everyday items, including the female body into the multiple layers of ceremonial kimonos. Even the Japanese practice and ritual that, to most, would seem to contradict this principle, that is, sumo, could be read as actually in keeping with it: bodies may clash in Japan, but only in an extremely ritualized way, in a liturgy in which they are indeed wrapped and coated with thick layers of adiposity.

Many everyday experiences would confirm the fact that the ease by which Japanese people would wear masks in times of potential colds and flus was actually part and product of a broader underpinning cultural configuration. On weekends, I would enjoy buying croissants and other traditional breakfast delicacies from the French bakery near my machiya in Kitaoji, in the northern part of Kyoto. I was amazed by how the shopkeeper would wrap each of my croissants individually, and each of my pains of chocolat also one by one, and then put all the individually wrapped croissants into one bag, and all the singularly wrapped pains au chocolat into another bag, and only then the two big bags into an even bigger one, where every bought 
item would be arranged into a plastic tree of Porphyry, into a fractal matrix of translucid veils separating each item from the others, each category of items from the others.

The widespread diffusion of protective masks in Japan was perhaps to be read in relation with such culture of wrapping, with a rooted semiotic ideology of immunity, according to which the best way to be part of the Japanese community was actually to interiorize and follow a systematic immunization of items and bodies, according to an orderly idea of the world where, even in a crowd of bodies or in a multitude of objects, each would occupy a specific space and a specific time, without any possibility of overlapping or clashing safe for ritualized occasions of orgiastic mixing (Shinto processions, for instance). According to this semiotic ideology, objects and bodies do not offer themselves to the external environment as they are, and following a random, spontaneous disposition in space and time, but with the idea that such exposure should not be immediate but mediated, filtered by cultural rules and even material devices working as masks or veils, changing the identity of objects before their encounter with the external world or channelling them through a multi-sensorial system of ostentations and occultations, prohibitions and permissions of the gaze.

The Medical Face Mask at the Moment of the 2020 Pandemic Outbreak

When the pandemic broke out in Europe and in the West, it did it in a sociocultural environment characterized by a different ideology of the face, affecting the way in which human visages are present in the public space, interact with each other, and adopt or reject a device such as the protective mask. Again, two anecdotic episodes will pave the way for more a systematic study of the protective mask in the western cultural semiotics during the epidemic. I was in Warsaw as a visiting professor when the epidemic exploded in northern Italy. I was supposed to go back to Turin, leave there my heavy luggage, and move the following day to Bordeaux, where I was expected for a public lecture. Instead, my flight from Poland to Italy was cancelled, and I had to fly directly from Warsaw to Bordeaux. Confinement rules were declared in Italy. I remained in Aquitaine some days after the lecture, decided to continue my research activities at the University of Limoges, but had to stop in La Rochelle, instead, because in the meantime the confinement was declared in France too. I have, therefore, spent most of the collective quarantine in the gracious French coastal town, the same where the present article is being written. 
As an Italian, I was aware of the gravity of the situation before the French were. In Italy, indeed, the confinement had been imposed one week earlier than in France. The day after President Macron imposed it in France too, with a public address during the evening French TV news program, I went early to the supermarket to buy some groceries. The confinement would start at noon on that same day. Many other people were there early, queuing in front of the supermarket before its opening, intent to make provisions for the imminent confinement too, yet none was wearing a mask; none except myself, who had bought an antidust and -pollution mask from a bicycle shop in Krakow, on my way to the local airport before moving to Bordeaux. In the grocery store at La Rochelle, on the last free morning before the confinement, other customers were now discreetly but worriedly looking at me, staring but pretending not to stare, distancing themselves from me at my passage along the narrow corridors of the supermarket as waters opening up at the passage of Moises through the Red Sea. I looked different with a mask on; I looked strange; and I also looked threatening, not only because I was visually received as potentially sick in a world of healthy people, but also because the face mask, in the western cultural semiotics, is inevitably associated with the necessity to conceal one's face in public and, hence, with the circumstance of having something to hide, a threat. In the west, before the pandemic, only robbers would wear a mask in grocery stores.

Second anecdote: the French confinement rules would allow people to take walks outside, maximum one hour, in the radius of one kilometre from one's home. I did so in a nearby park. I was wearing my mask. At some stage, a car approached me from the side; the driver, a lady in her fifties, put her window down and yelled, mockingly, "coin-coin", which is the French onomatopoeic expression for the cry of ducks. She, the driver, was not wearing a mask and was therefore make fun of me because I was wearing one and, thus, I would look like a duck to her eyes. That, moreover, did not happen at the beginning of the confinement but a month after its onset, when the pandemic had already killed thousands of people throughout France. The French culture of the face which that lady was implicitly voicing was one that would not admit wearing a protective mask in public. Furthermore, the culture of the face manifested by that mockery was also implicitly restating a deep-seated semiotic ideology, according to which human beings must show their face bare, with their mouth and nose and eyes visible, whereas those who conceal their mouth and nose under a mask turn their faces into snouts, they muzzle themselves with protective masks, they relinquish their humanity.

That anecdotic encounter was not an accident; it was produced by the same cultural configuration that, years earlier, had the Italian intellectual Roberto 
Calasso compare Japanese masks with beaks during a dinner conversation. Moreover, that rejection of the mask as detrimental to the humanity of the face in the public arena was reminiscent of a long and complex debate about the ethical value of the face, from Martin Buber to Emanuel Lévinas, from Deleuze and Guattari to Derrida and beyond. It was also part of an even broader, more encompassing issue: how far were human beings ready to go in order to protect themselves from the virus? In those same days, the philosophical blog written by another Italian world-famous intellectual, Giorgio Agamben, for the website of the publisher "Quodlibet", was generating widespread outcry, even among philosophers and admirers of Agamben's impressive body of work. He had been severely criticizing western democratic societies for imposing an-to him-undemocratic confinement, a state of exception that was threatening the rule of democratic law. In a way, that outcry was the philosophical version of the "coin-coin" yelled by the lady at myself along the road in a French park: were we ready to conceal our face, to look like non-human animals, just to preserve our health?

These and other episodes confirmed to me the necessity to develop an indepth semiotics of the protective mask, in connection with abroadersemiotics of the mask and to one of the veil, in order not only to better understand semiotic ideologies and cultural attitudes towards the face, but also in order to help satisfying the social demand of knowledge in a moment in which wearing versus not wearing masks was much more than a cultural choice; it was a social option with deep medical and public health consequences. Being the principal investigator of a European research project concerning the meaning of the face in the digital era, moreover, it was almost impossible not to reorient the focus of attention (my ownand that of myresearchteam) towardssuch complextopic:themedicalmask; its shapes, functions, and meanings; its cultures, counter-cultures, and practices.

The Need for a Semiotics of the Medical Face Mask

As scholars, semioticians need cognitive and emotional distance from their object. $^{8}$ That is difficult to guard in troubled times, when the object is close in temporal, spatial, and emotional terms. Yet, semioticians are intellectuals

8 As the present article is being written, medical face masks have not yet been made the object of scholarly semiotic literature, although contributions on these protective devices abound in medical bibliography and grey literature. As regards the former, see Osterholm and Kirton 2009; Seale 2009; Makison Booth 2013; Saunders-Hastings, et al. 2017; and Javid, Weekes, and Matheson 2020; as regards the latter, Canales 2020 is an interesting survey on visual propaganda concerning the wearing of masks during the 1918 'Spanish' influenza (mostly in San Francisco); the research team FACETs, led by the author of the present essay, has 
too. They must react to the urgency of circumstances as best as they can. Some events and phenomena, moreover, so characteristically solicit the skills of semioticians, that it would actually be even unethical of them not to reflect, not to respond, not to competently satisfy the social demand of knowledge. In the first half of 2020, the world has been through one of these situations, a pandemic that is still ongoing at the time this article is being written. Many scholars and intellectuals have contributed in their respective fields, seeking to improve the public understanding of the disruptive changes introduced by the global epidemic in every aspect of life. Semioticians and, more broadly, experts of language and communication have been concerned too: the whole range of human sign systems, from global digital social networks to everyday conversation, has been deeply affected by the unprecedented confinement of much of the population of the planet.

A new object, in particular, has entered the western semiosphere, as Jurij M. Lotman would call the abstract space of meaning-making and -sharing. The object is the protective, medical mask. It has entered the planetary sphere of signification and communication both as material item, with all its varieties, and as an object of public opinion and representation. The mask is a typical theme of ethnographic and anthropological enquiry. As it was seen in the first section, several essays have been written on the topic. Yet, the mask that has entered the global scene of communication, thus attracting the interest of semioticians too, is not a mask whatsoever but a particular one, that is, the medical mask, which in Italian is designated through the diminutive word "mascherina", "little mask". Classical philosophical and anthropological reflection on the mask is not unrelated to this new phenomenon, yet it must be adapted to the unparalleled circumstance of having much of the planet population wearing masks in public. These are still masks from a phenomenological perspective, but they require specific attention as regards their particular meaning in the extraordinary events of the current pandemic.

A general semiotics of the mask applies itself to an objective that is as difficult as that of a general semiotics of the veil, another object and semiotic device whose relation to the face and the semiosphere has also attracted the attention of scholars and semioticians. The two items are complexly related: a mask is also a sort of veil, and the veil is a kind of mask too. The complicacy, however, stems first of all from the slippery phenomenology of the material object itself, a phenomenology whose limits are only theoretically sharp, whereas, in reality, they are subject to a myriad of nuances. It is important, therefore, to proceed in an orderly manner, intertwining a chronology of the

published an open access digital book on medical face masks (Leone 2020); see also Leone Forthcoming. 
mask with a cartography of its meanings at each step of the spatio-temporal line of the pandemic. It is essential to write, together, a history and a semiotics of the medical mask. the Pandemic

Protective masks were not absent in the western semiosphere before the outbreak of the pandemic. Commonly, individuals would distractedly make the experience of themin specific circumstances.Typically, protectivemedicalmasks were worn by dentists and dental nurses, as well as by surgeons and their staff. As a consequence, protective masks were associated with the idea of medical treatment, but mostly in situations of traumatic medical intervention on and in the body. A patient would not normally see any medical masks, on the contrary, during a routine appointment with the family physician. Neither the family doctor nor the nurses would wear a protective face mask unless, again, in case of traumatic interventions on the body. It would be incorrect, therefore, to say that medical masks at the outbreak of the 2020 pandemic were associated with a semantic connotation of medicalization of the face; it would be more precise to say that the connotation was one of traumatic medicalization, of a situation in which contact between the doctor and the patient could entail a risk and a danger for both.

Protective masks were also worn in other non-medical contexts, by workers in polluted environments such as miners and construction workers, yet, again, they were associated to specific professions, in specific settings, and circumstantiate conditions.

When the pandemic broke out, common people in Italy as well as in most European and western countries were not used either to wear masks nor to see masks worn by other people. In this initial situation, the fact of someone wearing a mask in public, for instance in a plane or in public transport, would inevitably attract attention and, systematically, puzzlement mixed with preoccupation. "Why is this person wearing a mask?", was the implicit question that everybody would commonly wonder about. The implicit answer, in many cases, would be: "because this person is sick, contagious, and, therefore, potentially dangerous". As the pandemic burst out, therefore, the medical mask was commonly interpreted as an either intentional or unintentional, implicit or explicit sign of potential contagion, from the environment, of the person wearing it, and not, vice versa, as a sign of potential contagion of the environment by the person 
wearing the mask. Nervously and rapidly distancing oneself from the individual with the mask on was, as a consequence, the most typical reaction, almost a reflex.

When the pandemic flared up, and it became increasingly evident that the virus was transmitted through the human respiratory system, and China was already heavily hit, and people in most far east Asian countries were already making a massive use of medical masks, and images and videos of these masked Chinese and Asian population, including their political leaders, were already circulating in the global sphere of media, still, despite all these warning signs, the semantic connotation of masks in the western world would remain one of exceptional medicalization, even for people involved in global networks and intercontinental transport. The western 'culture of the mask', the deep-seated aversion to this object and its range of semantic meanings and pragmatic implications, would soon cost thousands of lives: when it was already too late, western countries and their pharmacies realized that they did not have enough masks, that an insufficient number of them was nationally produced, that people had started to wear them too late and only out of personal initiative, that most would not know how to distinguish between suitable and unsuitable types of masks, and that they would not know how to correctly use them. Even western governments and health organizations would instruct citizens that masks had to be worn only when displaying the likely symptoms of contagion, and not in order to protect oneself from it. This recommendation, however, as it was found out later and too late, was merely due to the fact that western countries did not have enough masks for everyone, not even for doctors in emergency rooms; on the one hand, they were trying to reserve the available masks for the most potentially risky environments, like hospitals and clinics; on the other hand, though, they were also contributing, thus, to the rapid spreading of the virus among unprotected people, including undersupplied doctors and nurses. A comparison with the campaign for the usage of condoms at the outbreak of AIDS is revealing: it was as though western governments had said, in that circumstance: please wear condoms when having sex, but only if you are displaying the likely symptoms of AIDS.

Various elements must be taken into consideration while developing a cultural semiotics of the medical mask. First of all, there is the object itself, a protective device that comes in several shapes, colours, and topological arrangements with 
the face, some of which being already programmed in the affordances of the object itself. The mask, in its variety of medical mask, is not normally worn for purposes of signification and communication. From this point of view, it is different, for instance, from a hat, or from a pair of sunglasses. Both can, indeed, be put on with the primary purpose of protecting the person wearing them from external and, possibly, harmful agents, like cold wind or strong sunlight. Yet, in both these latter cases, an established cultural tradition has already turned such functional objects into semiotic and communicative devices, which can be even dissociated from their practical protective function and displayed and/ or received as purely aesthetic devices. As a consequence, they can give rise to a process of diversification and customization that is typical of ornamental items, a process through which they can contribute to compose the personal style of those who wear them. They can also, as a result, become items in the circuit of fashion, and acquire different values depending on their shape, color, and artistic genealogy.

The same process can take place also for medical masks, although more as a represented item than as a properly worn one. That is the case because the denotation of the medical mask as a functional, protective, and exceptional object is much stronger than that of hats or sunglasses. In the case of the protective mask, it is difficult not to see it as a medical device, especially in a cultural area, like the western one, where its connotation is inseparable from an idea of emergency, risk, and danger. The medical mask is better comparable to other medical objects like crutches, for instance: no matter to what extent they are re-appropriated in aestheticandpersonalterms, thesignification thatstemsfrom theirmedicalfunction remains predominant.

As semioticians have underlined from Barthes and Eco on, however, the function itself of an object is also a content of its signification. When people see me going out with an umbrella, they will think that it might rain, that I think that it might rain, or, if the sky is completely clear, they might think that something is wrong with me, or that I am about to leave for a long journey toward a rainy destination. I might also have a colourful umbrella, or a particularly fancy one, or one that is branded by a famous designer, yet its function will remain its primary semantic content, unless I happen to be in a cultural area where this primary functional meaning itself is different. On a summery and torrid day in the Baoshan campus of the University of Shanghai, for instance, students and especially girls go out with umbrellas so as to protect themselves from the sun, so that it would be absurd to infer, from seeing one of such tools, that it might likely rain.

As I go out of my house with a medical mask on, this mask primarily signifies its function, yet this function is not so clear as that of an umbrella, for two 
reasons. First, it is evident who will be protected by an umbrella from what. The potentially negative agent here is the rain or, alternatively, the sun in far east Asian societies, and the potential victim to protect here is clearly the one who is carrying the umbrella. But who, or what, are masks protecting those wearing them from? The negative agent here is twice invisible, first, because it is not possible to know who is already infected in the public space, and often even those who are already infected ignore it, and, second, because it is not clear where the virus is, whether only in droplets coming from other people's breathing, sneezing, coughing, and talking, or also on surfaces, objects, and even in the air. Scientific information about where the virus might be in the public sphere is not always consistent, research on the topic is still ongoing, tons of disinformation and fake news circulate, and it is not always easy, for common citizens, to make up their minds. Most of them, therefore, go out wearing a mask thinking that the virus could potentially be everywhere, and that everyone come across in the street might actually be infected and a source of possible contagion.

There is also a second reason for the unclear functional message that a medical mask conveys in the public space. As I wear it out of the house, its meaning will be threefold, like the meaning of every communicative device: 1) what I mean by wearing a mask; 2) what is meant to people when I wear a mask; 3) what is meant by the mask itself. The first type of meaning, or intentio auctoris, might most often coincide with the functional content of the mask itself, although always with the peculiarities described in the first point: I wear a mask because I want to protect myself from a potentially dangerous environment, and I do not want to communicate anything special to anyone. That might not be the case, however, when I am actually in the situation of having to communicate something through the mask. If I am a cook working at a restaurant, for instance, I might wear a medical mask in a purely functional way, but I shall also be probably aware of the fact that, through wearing it, I likely signify something else too. This something else depends on how an interpretive community has already been taking shape around the cook; if the mask is still an exotic object, then wearing it might even send out a counterproductive message: the cook is maybe sick, he or she does not want to contaminate food; on the contrary, if the presence of medical masks in the social space has reached critical mass, then the likely message sent out by the cook wearing the mask will be exactly opposite: I am a responsible worker, I am likely healthy but, in any circumstance, I know that I might be not and, in such case, it is safer for everyone that I wear a mask, also in order to protect myself from potential contagion from coworkers, customers, manipulated objects, and the environment. 
As regards point 2), that is, the intentio lectoris of the mask, i.e., what the mask signifies to people who see it worn by someone else, including themselves in the mirror, much depends on the 'context', but the context ultimately consists in the 'common sense' that is generated by the constitution of a 'community of interpreters'. In this case too, at the beginning of a pandemic, when most people are still unaware of the extreme contagiousness of a virus, the mask will give rise to emotional reactions of puzzlement, preoccupation, fear or, conversely, to irony and mocking. On the contrary, as the pandemic spreads, and an increasingly number of masks populate the social and visual public space, then the interpretive community and its common sense change too, altering the context in which the mask produces its communicative effect. The reaction will not be any more: "this person is maybe sick"; or "this person is hypochondriac"; but, rather, "this person is cautious, he or she wears a mask exactly like me". With the proceeding of the pandemic and the establishment of new common semiotic habits, the interpretive community might actually be completely reversed; a person not wearing a mask might eventually end up being frowned upon by a community that considers her or him as a potential danger.

That is why, looking forward, exactly as it has been difficult to get western communities accustomed to the generalized wearing of medical masks, it might also turn out as or even more difficult, in the future, that people get used not to wear their masks in public. Semiotic habits begotten by the pandemic might actually linger in the public space well after the pandemic is gone. People might, for instance, at least in the near future, not taking planes without protective medical masks any longer, giving rise to a masked public sphere similar to that which would characterize those of far east Asian countries even before the outbreak of the pandemic.

The situation is complicated by the fact that the uncertainty of the pragmatics of contagiousness characterizes both poles of the communicative axis: on the one hand, one is uncertain about the healthiness and non-contagiousness of other individuals, including close relatives and friends; on the other hand, one is also intrinsically uncertain about one's healthiness and non-contagiousness, the only way to be totally sure about it being to have oneself medically tested or undergoing a long quarantine. The presence of the virus in a society, and the inexistence of vaccinations, brings about a game theory situation in which the best choice will always be, for everyone, that of wearing a mask.

But that leads to the discussion of the third type of meaning associated with this object, that is, its intentio operis. No matter how difficult it might be to determine the intrinsic meaning of an artefact within a community of users and interpreters - in terms of both functional signification and intertwined 
re-semantisations - the range of such core semantic contents cannot be conceived as infinitely stretchable; in other words, it would be unreasonable to think that, in a community of meaning, the medical mask means everything and nothing. Such range, indeed, is inherently limited by, first, the form of the mask itself, which is in close connection with its function. Curious ethnographers might realize, for instance, when queuing outside an Italian supermarket during the pandemic, that protective masks worn by prospective customers come in various forms and shapes, even including objects that, while clearly not being masks, are worn as such, so as to approximately replace their functions; when the Northern Italian region of Lombardy introduced the legal obligation for everyone to wear a mask when in public - but it was clear that not everybody would have been able to obtain a medical mask of whatsoever kind - the Region's Government itself prescribed that masks could have been replaced, in exceptional cases, by scarves worn so as to cover one's mouth and nose. Ironic representations of this dramatic injunction multiplied, of course.

Ethnographers in line in front of a supermarket during the epidemic would also realize, however, that masks do not vary only in type, shape, and color, including, as it was said earlier, non-masks worn as masks, but that they vary also as regards the different ways in which they are worn: some people nervously check every second that their mouths and noses are perfectly covered; some others tuck their masks underneath the rim of their eyeglasses so as to better cover the face and avoid that the lenses get foggy; some others yet take the mask temporarily off the face, letting it hang from one ear or from both ears, because they are too hot, and they judge that they are sufficiently distant from other customers, or because they need to be face-recognized by their own phones, or for other reasons; some people even push their masks up on their foreheads, and there are also those geniuses, heavily mocked in social networks, who partially remove their masks so as to put the temples of their glasses in their mouths.

But that is nothing new: people do all sorts of strange things with their glasses for instance, or, to take an example that is even closer to the present case-study, one should think of the multiple ways in which the legal obligation for women to wear a scarf on their head, currently enforced in Iran, is variously re-semantised by Iranian female citizens, depending on as many factors as age, social and economic class, religious and politic believes, the specific social occasion with its spatial and temporal coordinates, as well as individual temperament, turning the obligatory scarf into one more fashion item with which women intentionally or distractedly compose their peculiar dressing style. The range of possible re-semantisation of the medical mask is maybe not as large as that of the possible re-arrangements of the obligatory Islamic 
veil, and it will never be: protecting one's lungs from the virus and protecting one's female hair from the male gaze are quite different semiotic operations; yet, it is certainly only a matter of time before the medical mask ceases to be, in the west too, a monolithic object and starts differentiating even further into a myriads of personal usages.

Nevertheless, it would be bad semiotics to think that, given this turning of the medical mask into an everyday object with multiple uses, the range of its meanings disintegrates into a deconstructive realm with no internal grammar, into a kaleidoscope of personal usages with no common features. Affirming this ideological nonsense would be tantamount to saying that, since there are many metaphorical usages of the word "leg", then the common meaning of such word cannot be grasped. As Umberto Eco would tirelessly repeat, on the opposite, metaphorical usages of a word can exist exactly insofar as such metaphorical force can be measured as deviation from the semantic bottom line that defines the common meaning of the word itself in a language and its community of speakers, a bottom line that is the reference in relation to which the semantic deviation of the metaphor is appraised and appreciated, a literary meaning that is, moreover, transmogrified into lexical definitions in dictionaries.

In the same way, although many usages of the medical mask exist, some of which being frankly quite bizarre, a semantic core of this artefact can still be grasped, no matter the large extent to which it is re-semantised in the public sphere. Such core is defined, first of all, by the affordances of the mask; a common surgical mask must be worn around one's ears and over one's mouth and nose, and every alternative hanging and wearing can have only limited diffusion for it would affect the efficacy of the mask itself. Second, the common semantic core is defined by the mask's basic function: although in Japan young (predominantly) female individuals might use the mask to protect their shyness from alien gazes in the public space, that is doomed to remain an aesthetic, scopic connotation on top of the basic denotation of the mask, which remains in the medical sphere. No matter what, indeed, the diffusion of protective masks in the public space will always mean that something is wrong with the quality of the air, and that breathing with no protection is potentially harmful, either because of the pollution or because of the presence of a virus in the air amidst people.

In other words, the object 'medical mask' is so deeply connected with the dysphoric situation of the pandemic that it is highly unlikely that it will turn into a habit or a fashion with no negative meaning attached to it. In a certain sense, a similar phenomenon has affected the diffusion of condoms: likely, 
more and more male individuals in the world wear them before having sex in order to avoid causing undesired pregnancies or the transmission of STDs; in any case, despite the efforts of global brands to turn condoms into ludic objects with different colours and shapes, wearing them will always signify, for the majority of people, a procedure of immunity, and the possibility that something undesirable, from an unplanned pregnancy to a lethal disease, results from having sex with a partner.

That does not imply that the meaning of masks is not subject to semantic fluctuations. The comparison between the current Japanese and the presentday communicative reception of medical masks in the West demonstrates that this is not the case. On the contrary, it can be hypothesized that the intrinsic meaning of masks, albeit constituted by a semantic core of affordances and a basic medical denotation, fluctuates in a community of interpreters depending on the number of people who adopt this medical device. That is already evolving in several European countries.

\section{Conclusions: the Impossibility of a Habit}

During the now almost two months of confinement in my little apartment in the proximity of the old harbour at La Rochelle, I have developed the habit to observe the few passersby that walk under the three windows of my sitting room; in the beginning I would say to myself: "look, a jogger with a mask!"; or "look, a couple of elderly people, both wearing masks"; after two months, the situation of the pandemic in France has unfortunately changed in such a way that now I find myself thinking: "look, a rider without a mask!"; "look, a punk family not wearing any masks!" Most European societies, indeed, have already transitioned from the stage in which the mask would indicate poor health (like in the case of oncological patients in airplanes, for instance), possible contagiousness, or hypochondria, to the stage in which they simply mean the intention to protect oneself, one's relatives, but also one's community, from the spreading of the contagion. As it was suggested earlier, it is unlikely that the curve of diffusion of masks in the public space will flatten together with the flattening of the curve of diffusion of the virus itself in society; masks will be worn and seen for a certain time even after the end of the pandemic.

Yet, the diffusion of masks in the physical space cannot be fully understood without considering that it intertwines with the diffusion of representations of masks in the communicative and especially digital space. In this case too, representations seem to follow a sort of curve, whose trend parallels those of 
the spreading of the virus and the diffusion of physical masks. When the epidemic was still far, in remote Wuhan, and Europeans would foolishly believe that it could be confined there, medical masks were absent in the physical public space in Italy, for they were worn only in Chinese enclaves within Milan or Prato and by some of those having business or personal contacts with China (but not by all of them, unfortunately). As the epidemic 'approached' and became more and more present in Northern Italy, medical masks started to appear in the digital social space earlier than in the physical one. Most of these representations, however, were nervously ironic; some of them, especially in the beginning, were on the verge of political incorrectness, bearing on the relation between China and the virus. As the virus spread, however, masks started to appear on digital representations of famous paintings, classical statues, objects, and even the entire range of emojis was endowed with masks. At the same time, the most popular formats of face representation in the digital sphere were readapted so as to include the new medical devices, and selfies with masks started to pop out throughout social networks. Different attitudes were represented, which, in general, confirmed those of the masked photographers; narcissistic personalities appeared with fancy masks, ironic ones with badly worn masks or with masks in improbable settings, or either in contexts underlining one's clumsiness in wearing such new devices. As the pandemic broke out, however, and the number of deceased patients flared up, ironic representations went down. Irony and sarcasm indeed imply the possibility of a certain distance, yet it was increasingly evident that, sooner or later, the virus would spread everywhere in the world. As the pandemic was peaking in Italy, France was still immune, or it thought it was, and a French bad joke about Italian pizza makers spreading the virus started to circulate in French media; yet, a week later, France too was in the same situation, and nobody wanted to joke about the virus anymore. Irony on masks continued, and ironic representations of masked political leaders multiplied in the memes, yet the masked selfies decreased, since wearing a mask was not a joke anymore but a necessity, and one, moreover, that could not be always satisfied given the lack of medical masks. Heroic selfies of doctors and nurses with protective masks on, fighting the virus in hospitals and clinics, started to appear, yet they were more self-portraits than selfies, with nothing in their backgrounds but blurry hospital sceneries, tragic hints to suffering and death.

As the present article is being written, it is still uncertain when and even if the pandemic will come to an end. Experiments on vaccinations are ongoing, but will result in medical products only in several months if not years from now. In the meantime, protective masks are increasingly becoming a dramatic everyday object. I still have a set of few surgical masks that I bought in Warsaw at the outbreak of the pandemic in Italy; masks went immediately out of stock 
there, but I could still find a package of them in Poland. I wear them when groceries are delivered to my confinement apartment at La Rochelle, or when I go through the time-consuming process of disinfecting them, as I was recommended to do by my Chinese students and colleagues. I have another thicker mask, moreover, with a washable filter, the one bought in the bicycle store in Krakow, that I wear when I take my weekly walk around my house, to the old harbour. Yet, I cannot get used to it, as I cannot get used to its being worn by the few people I come across along my short walk. After all, the face is a fundamental interface of human interaction. Interpersonal communication has always been based on seeing the other's face and on showing one's face to the other. ${ }^{9}$ Fluctuations about this rule might have taken place in space and time, with the re-semantisation of medical masks in far east Asia, with the introduction of the Islamic veil-also very problematic in the west—with the fashion of large sunglasses and even full masks in trap music. All these fluctuations, however, could not make sense without reference to the fact that, in normal circumstances, people interact face to face, seeing each other's visages. These fluctuations do not rule out, either, that covering one's mouth with a mask, as well as seeing other people's mouths covered by masks, dramatically modify the gestalt of visages in face to face interaction. We cannot see anymore the labial of conversations; the facial origin of verbal language and smile is occulted to us. As I walk along the deserted streets of La Rochelle, I cannot ban from my head the thought that my mask is casting on my face and on other people's visages an impossible shadow of sadness, an unchanging expression of sorrow, a transformation of the face into an immobile façade, in which only the eyes are left to express, with a nervous movement, the desolation of defacement. May we humans recover our faces soon.

\section{References}

André, Jacques, Dreyfus-Asséo, Sylvie, and Taylor, Anne Christine (2010) Psyché: Visage et Masques. Paris: Presses Universitaires De France.

Barthes, Ronald (1957) Mythologies. Paris: Seuil; Engl. trans. by Annette Lavers. New York: Farrar, Straus, \& Giroux - The Noonday Press.

Belting, Hans (2013) Faces: Eine Geschichte Des Gesichts. München: C. H. Beck.

Berlejung, Angelika and Filitz, Judith E. (2018) The Physicality of the Other: Masks from the Ancient Near East and the Eastern Mediterranean ("Orientalische Religionen in der Antike", 27). Tübingen: Mohr Siebeck.

9 There are, however, significant exceptions, like the Tuareg people (Grimes 1975). 
Bettini, Maurizio, ed. (1991) La maschera, il doppio e il ritratto. Strategie dell'identità. Rome and Bari: Laterza.

Beyaert-Geslin, Anne (2017) Sémiotique du portrait : De Dibutade au Selfie ("Culture \& Communication"). Louvain-la-Neuve: De Boeck Supérieur.

Birdwhistell, Ray L. (1970) Kinesics and Context: Essays on Body Motion Communication. Philadelphia, PA: University of Pennsylvania Press.

Buch, Marina-Rafaela (2019) Le Théâtre nippon dans le théâtre français du XXe siècle: D'un regard kaléidoscopique à une réception productive ("Romanica", 8). Göttingen and Mainz: V\&R Unipress; Mainz University Press.

Canales, Katie (2020) “These Surprisingly Relevant Vintage Ads Show How Officials Tried to Convince People to Wear Masks after Many Refused during the $1918 \mathrm{Flu}$ Pandemic", Business Insider, 10 May 2020; available at the website https://www .businessinsider.com/people-vintage-mask-ads-spanish-flu-1918-pandemic-2O2O -5 ?IR=T\#the-spanish-flu-outbreak-coincided-with-world-war-l-male-soldiers -returning-home-from-europe-dispersed-to-their-home-states-and-stations -spreading-the-disease-in-the-process-3 (last access 22 May 2020).

Chateau, Dominique (2006) "Stéréotype, prototype et archetype: À propos du Portrait de Gertrude Stein de Picasso", in Bernard Darras (ed.), Images et sémiotique: Sémiotique pragmatique et cognitive ("Collection Esthétique 8 - Série Images Analyses"). Paris: Publications de la Sorbonne, 147-61.

Chazot, Eric, Brotherton, Barbara, and the Rubin Museum of Art (2015) Becoming Another: The Power of Masks. New York: Rubin Museum of Art.

Crocker, J. Cristopher (1977) “The Mirrored Self: Identity and Ritual Inversion among the Eastern Bororo", Ethnology 16(2): 129-45.

Crumrine, N. Ross (1983) "Masks, Participants, and Audience", in N. Ross Crumrine and Marjorie M. Halpin (eds), The Power of Symbols: Masks and Masquerade in the Americas. Vancouver: University of British Columbia Press, 12-18.

Dagan, Esther A. (1992) The Spirit's Image: The African Masking Tradition: Evolving Continuity. Montréal: Galerie Amrad.

Eco, Umberto (1975) Trattato di semiotica generale. Milan: Bompiani; Engl. version Eco, Umberto (1976) A Theory of Semiotics (Advanced in Semiotics). Bloomington and London: Indiana University Press.

Edson, Gary (2005) Masks and Masking: Faces of Tradition and Belief Worldwide. Jefferson, NC: McFarland \& Co.

Eliade, Mircea (1964) "Masks: Mythical and Ritual Origins", in Bernard S. Myers (ed.), Encyclopedia of World Art, 17 vols. New York: McGraw-Hill, 9, 521-6.

Ferino Pagden, Sylvia et al. (2009) Wir sind Maske. Cinisello Balsamo, Milan and Wien: Silvana; Kunsthistorisches Museum. 
Filitz, Judith E. (2018) Masken im Altertum: Zwischen Religion und Kunst ("Zaberns Bildbände zur Archäologie"). Darmstadt: Verlag Philipp Von Zabern.

Gell, Alfred (1975) Metamorphosis of the Cassowaries: Umeda Society, Language and Ritual. (London School of Economics. Monographs on Social Anthropology, 51.). London: University of London, Athlone Press; New Jersey: Humanities Press.

Goffman, Erwin (1959) The Presentation of Self in Everyday Life. Garden City, NY: Doubleday.

Greco, Cristina. 2009. Con la china in testa: fumetto e memoria culturale; per una lettura di Maus e Palestina. Padua: libreria universitaria.

Grimes, Ronald L. (1975) "Masking: Toward a Phenomenology of Exteriorization", Journal of the American Academy of Religion 43(3): 508-16.

Heath, Jennifer (2008) “What is Subordinated, Dominates': Mourning, Magic, Masks and Male Veiling", in Jennifer Heath (ed.), The Veil: Women Writers on Its History, Lore, and Politics. Berkeley, CA: University of California Press, 99-118.

Hershman, Debby, et al. (2014) Face to Face: The Oldest Masks in the World. Jerusalem: Israel Museum.

Honigmann, John J. (1977) “The Masked Face”, Ethos 5(3): 263-8o.

Inglis, David (2018) "Cover their Face: Masks, Masking, and Masquerades in HistoricalAnthropological Context”, in Anna-Mari Almila and David Inglis (eds), The Routledge International Handbook to Veils and Veiling Practices. London and New York: Routledge, 278-91.

Javid, Babak, Weekes, Michael, and Nicholas, Matheson (2020) "Covid-19: Should the Public Wear Face Masks?", M1442. BMJ: British Medical Journal (Online), 369.

Jedrej, M. C. (1980) "A Comparison of Some Masks from North America, Africa, and Melanesia", Journal of Anthropological Research 36: 220-30.

Leone, Massimo, Henri de Riedmatten, and Victor I. Stoichita, eds. (2016) Il sistema del velo: Trasparenze e opacità nell'arte moderna e contemporanea / Système du voile: Transparence et opacité dans l'art moderne et contemporain. [I saggi di Lexia 19]. Rome: Aracne.

Leone, Massimo. 2007. "Cultures of Invisibility: The Semiotics of the Veil in Ancient Rome", in Semio Istanbul 2007. Proceedings of the 8th congress of the International Association for Visual Semiotics held in Istanbul, June 2007. Istanbul: Istanbul Kültür Üniversitesi: 1069-79.

Leone, Massimo (2009) "Cultures of Invisibility: The Semiotics of the Veil in Ancient Judaism”, In Donia Cmeciu and Traian D. Stănciulescu (2009) Transmodernity: Managing Global Communication. Proceedings of the II Congress of the Romanian Association for Semiotics (Bacău, October 2008). Bacău: Alma Mater Publishing House, 189-201. 
Leone, Massimo (2010) "Remarks for a Semiotics of the Veil", Chinese Semiotic Studies $4(2): 25^{8}-278$.

Leone, Massimo (2011) "Le Voile de Timanthe: Essai d'articulation sémiotique", NAS: Nouveaux Actes Sémiotiques, online; published on October 31, 2011; available at http://revues.unilim.fr/nas/document.php?id=4036.

Leone, Massimo (2014a) "Cultures of Invisibility: The Semiotics of the Veil in Ancient Christianity", Gramma 20: 273-86.

Leone, Massimo (2014b) “The Veil of Tamar", Interfaces: Image Texte Langage (College of the Holy Cross / Université Paris Vir Denis Diderot), 35:113-23.

Leone, Massimo (2016) "Microanalisi del velo. Verso una semiotica del drappeggio", in Massimo Leone, Henri de Riedmatten, and Victor I. Stoichita (eds), Il sistema del velo: Trasparenze e opacità nell'arte moderna e contemporanea / Système du voile: Transparence et opacité dans l'art moderne et contemporain. [I saggi di Lexia 19]. Rome: Aracne, 131-51.

Leone, Massimo (2017) "Homo velans: Paradossi del velo nella semiosfera contemporanea”, in Marianna Ferrara, Alessandra Saggioro, and Giusi Viscardi (eds), Le verità del velo ("Alti Studi di Storia intellettuale e delle Religioni"). Florence: Società Editrice Fiorentina, 27-45.

Leone, Massimo (2018) “Imagining the Absolute: The 'Veil of Maya' as Semiotic Device", in Diana Teters and Otto Neumaier (eds), Metamorphoses of the Absolute. Newcastle upon Tyne, UK: Cambridge Scholars Publishing, 39-52.

Leone, Massimo (2018) “La ropa tendida al sol: velos y revelaciones", La Tadeo Arte 4(4) (December): 56-73.

Leone, Massimo (2020) Volti virali. Turin: FACE TS Digital Press.

Leone, Massimo (Forthcoming) "Le masque et la muselière : Variations de l'animalité en temps de pandémie”, forthcoming. Degrés : Revue de synthèse à orientation sémiologique.

Lévi-Strauss, Claude (1975) La Voie des masques, 2 vols ("Les Sentiers de la creation" 24, I-II). Geneva: A. Skira; Paris: diffusion Flammarion.

Mack, John (1994) Masks and the Art of Expression. New York: H. N. Abrams.

Makison Booth, C. et al. (2013) "Effectiveness of Surgical Masks against Influenza Bioaerosols", Journal of Hospital Infection 84(1): 22-26.

Markman, Roberta H. and Peter T. Markman (1989) Masks of the Spirit: Image and Metaphor in Mesoamerica. Berkeley, CA: University of California Press.

Marsciani, Francesco (1990) “La maschera neutra”, Carte semiotiche 7 (June): 146-16o.

Mesnil, Marianne (1976) “The Masked Festival: Disguise or Affirmation?”, Culture, 3(2): 11-29.

Murphy, Robert F. (1964) “Social Distance and Veil”, American Anthropologist 66(6): 1257-74. 
Napier, A. David (1987) Masks, Transformation, and Paradox. Berkeley, CA: University of California Press.

Nunley, John W. and McCarty, Cara (eds) (1999) Masks: Faces of Culture (catalogue of the homonymous exhibition, St. Louis Art Museum, St. Louis, Mo., Oct. 9, 1999Jan. 2, 2000; The Field Museum, Chicago, Feb. 19-May 14, 2000; and the Museum of Fine Arts, Houston, Tex., June 25-Oct. 1, 2000). New York: Abrams in Association with The St. Louis Art Museum.

Oettinger, Marion and Kenagy, Suzanne (1988) "The Many Faces of Mexico: Masks in Cultural Context", Masterkey 62(2/3): 9-22.

Ogibenin, Boris L. (1975) "Mask in the Light of Semiotics: A Functional Approach", Semiotica 13(1): 1-9.

Osterholm, Michael T. and Kirton, John J. (2009) "Preparing for the Next Pandemic", in Kirton, John J. (ed.), Global Health. London and New York: Routledge, 225-38.

Pernet, Henry (1992a) Ritual Masks: Deceptions and Revelations ("Studies in Comparative Religion"). Columbia, SC: University of South Carolina Press.

Pernet, Henry (1992b) "Masks and Women: Toward a Reappraisal", 45-59. History of Religions 22, 1: 45-59.

Pollock, Donald (1995) "Masks and the Semiotics of Identity", 581-98. Journal of the Royal Anthropological Institute, 1, 3 .

Ricca, Mario (2020) “Don't Uncover that Face! Covid-19 Masks and the Niqab: Ironic Transfigurations of the ECtHR's Intercultural Blindness", International Journal for the Semiotics of Law: Revue internationale de Sémiotique juridique, 30 April 2020: $1-25$.

Sanou, Noël (2019) "Poétique et sémiotique : configuration de la langagité du masque", Signata 10 (30 June 2019): online; available at the website http://journals.openedition.org/signata/2381 (last access 22 May 2020).

Saunders-Hastings, Patrick, et al. (2017) "Effectiveness of Personal Protective Measures in Reducing Pandemic Influenza Transmission: A Systematic Review and Metaanalysis", Epidemics, 20(C.): 1-20.

Seale, Holly, et al. 2009. "A Review of Medical Masks and Respirators for Use during an Influenza Pandemic", Influenza and Other Respiratory Viruses, 3(5): 205-6.

Synnott, Anthony (1989) "Truth and Goodness, Mirrors and Masks; Part I: A Sociology of Beauty and the Face", The British Journal of Sociology 40(4): 607-36.

Synnott, Anthony (1990) "Truth and Goodness, Mirrors and Masks Part II: A Sociology of Beauty and the Face", The British Journal of Sociology 41(1): 55-76.

Tonkin, Elizabeth (1979) "Masks and Powers", Man (New Series) 14: 237-48.

Tseëlon, Efrat (1995) The Masque of Femininity: The Presentation of Woman in Everyday Life. London: Sage. 
Tseëlon, Efrat (2001) “Introduction: Masquerade and Identities", in Id.(ed.), Masquerade and Identities: Essays on Gender, Sexuality and Marginality. London and New York: Routledge, $1-37$.

Tseëlon, Efrat (2014) "Fashion and the Orders of Masking", Critical Studies in Fashion and Beauty 3(3-9): 237-48.

Twycross, Meg and Sarah Carpenter (2016) Masks and Masking in Medieval and Early Tudor England ("Studies in Performance and Early Modern Drama"). London and New York: Routledge.

Urban, Gregg and Wall Hendricks, Janet (1983) "Signal Functions of Masking in Amerindian Brazil", Semiotica 47: 181-216.

Volli, Ugo (2013) "Riflessione e trascendenza di una maschera", in Massimo Leone and Isabella Pezzini (eds.), Semiotica delle soggettività (per Omar) ("I saggi di Lexia", 11). Rome: Aracne, $265-78$.

Walens, Stanley (1983) "Analogic Causality and the Power of Masks", in N. Ross Crumrine and Margorie Helpin (eds), The Power of Symbols: Masks and Masquerade in the Americas. Vancouver: University of British Columbia Press, 70-8.

Zang Ndong, Pascaline (2017) "Écriture et masque : Approche sémiotique et poétique", Doctoral Dissertation in Semiotics, University of Limoges, France. 